\title{
Hydrogen peroxide induces cell proliferation and apoptosis in pulp of rats after dental bleaching in vivo
}

\author{
Effects of the dental bleaching in pulp
}

\author{
Francine Benetti ${ }^{\mathrm{a}}$, João Eduardo Gomes-Filho ${ }^{\mathrm{a}}$, Luciana Louzada Ferreira ${ }^{\mathrm{a}}$, Edilson Ervolino ${ }^{\mathrm{b}}$, \\ André Luiz Fraga Briso ${ }^{c}$, Gustavo Sivieri-Araújo ${ }^{a}$, Eloi Dezan-Júnior ${ }^{a}$, \\ Luciano Tavares Angelo Cintra ${ }^{\mathrm{a}, *}$
}

a Endodontics, São Paulo State University (Unesp), School of Dentistry, 16015-050, Araçatuba, SP, Brazil

b Basic Science, São Paulo State University (Unesp), School of Dentistry, 16015-050, Araçatuba, SP, Brazil

c Restorative Dentistry, São Paulo State University (Unesp), School of Dentistry, 16015-050, Araçatuba, SP, Brazil

\section{A R T I C L E I N F O}

\section{Keywords:}

Hydrogen peroxide

Pulp tissue

Tooth bleaching

Proliferating cell nuclear antigen

Caspase 3

\begin{abstract}
A B S T R A C T
Objective: This study provides an in vivo evaluation of the inflammatory response, levels of cell proliferation and apoptosis, and the presence of necrosis after dental bleaching with two concentrations of hydrogen peroxide $\left(\mathrm{H}_{2} \mathrm{O}_{2}\right)$.

Design: Wistar rats were divided into Control (placebo gel), BLUE $\left(20 \% \mathrm{H}_{2} \mathrm{O}_{2}, 1 \times 50 \mathrm{~min}\right)$, and MAXX (35\% $\left.\mathrm{H}_{2} \mathrm{O}_{2}, 3 \times 15 \mathrm{~min}\right)$ groups. At 2 and 30 days, the rats were killed $(\mathrm{n}=10)$. The jaws were processed for histology analysis and PCNA and Caspase-3-cleaved immunohistochemistry, and data were submitted to the Mann-Whitney or ANOVA test $(P<0.05)$

Results: At 2 days, the MAXX group showed necrosis and the BLUE group revealed moderate inflammation on the occlusal third of the crown $(P<0.05)$. At 30 days, tertiary dentin had formed and there was an absence of inflammation. The level of cell proliferation was higher in the middle third of the BLUE group $(P<0.05)$, and cervical of MAXX at 2 days $(P<0.05)$, decreasing at 30 days. The apoptosis was present at 2 days, particularly in the cervical third of the crown in the bleached groups $(P<0.05)$, with a decrease only at 30 days in the BLUE group $(P<0.05)$.

Conclusions: The concentration of $\mathrm{H}_{2} \mathrm{O}_{2}$ influences effects on the pulp tissue, where a higher concentration of $\mathrm{H}_{2} \mathrm{O}_{2}$ can cause necrosis in the pulp and a prolonged effect within the apoptotic process; lower concentrations of $\mathrm{H}_{2} \mathrm{O}_{2}$ provide moderate inflammation, cell proliferation and apoptosis with a reduction of these processes over time.
\end{abstract}

\section{Introduction}

Hydrogen peroxide $\left(\mathrm{H}_{2} \mathrm{O}_{2}\right)$ is widely used in different concentrations as a bleaching agent. It acts through the releasing reactive oxygen species (ROS) that provides the change in the hardness of the enamel (Azer, Machado, Sanchez, \& Rashid, 2009), and in the chemical composition of enamel and dentin (Bistey, Nagy, Simo, \& Hegedus, 2007). It has the ability to reach the pulp through the dentinal tubules causing decreased cellularity and cellular metabolism (Cintra et al., 2013; Min et al., 2008; Seale, McIntosh, \& Taylor, 1981; Soares, Basso, Scheffel, Hebling, \& de Souza Costa, 2015), changes in vascular permeability (Ferreira et al., 2013), and DNA damage in cells (Sanz, Gómez,
Caro, \& Barja, 2006), leading to the necrosis of tissue (Cintra et al., 2013; Cintra, Benetti, Ferreira, Rahal et al., 2016; Costa, Riehl, Kina, Sacono, \& Hebling, 2010; Roderjan et al., 2014; Roderjan et al., 2015).

Our previous study in rats' molars showed that the $\mathrm{H}_{2} \mathrm{O}_{2}$ caused necrosis in the oclusal third of the coronary pulp after one bleaching session (Cintra et al., 2013). The same outcome was found in studies on human teeth (Costa et al., 2010; Roderjan et al., 2014; Roderjan et al., 2015). Studies in dogs' teeth also showed severe changes in dental pulp in the first days after dental bleaching (Seale et al., 1981). These changes may be related the fact that most patients relate postoperative sensitivity after dental bleaching (Bonafé et al., 2013), especially after the use of high concentrations of $\mathrm{H}_{2} \mathrm{O}_{2}$ (Pintado-Palomino, Peitl Filho, Zanotto, \& Tirapelli, 2015).

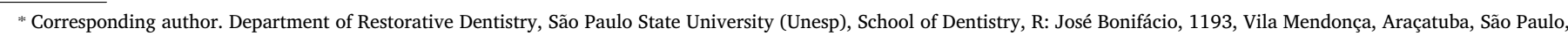
Brazil.
}

E-mail address: lucianocintra@foa.unesp.br (L.T.A. Cintra). 
However, in vivo (Seale et al., 1981) and in vitro studies (Soares, Basso, Hebling, \& de Souza Costa, 2015) showed that, after a certain period, the pulp tissue recovers its organization and the pulp cells regains its viability values. We observed these results even in pulp tissue of diabetic rats (Cintra, Ferreira et al., 2016; Ferreira et al., 2017). Recent attention is being given to the fact that a small amount of ROS increases cell differentiation (Matsui, Tsujimoto, \& Matsushima, 2007). It is believed that, at a low concentration, the $\mathrm{H}_{2} \mathrm{O}_{2}$ stimulates cells to perform functions (Davies, 1999) with a more complex role in cell physiology than causing solely oxidative damages (Lee, Lim, Lee, \& Yang, 2006; Matsui et al., 2007; Matsui, Takahashi, Tsujimoto, \& Matsushima, 2009; Wu, Li, Du, Jiang, \& Zhu, 2013). However, the literature lacks studies to help elucidate the cellular mechanisms that involve the pulp tissue after contact with $\mathrm{H}_{2} \mathrm{O}_{2}$ permeation during the dental bleaching process.

The Proliferation of Cell Nuclear Antigen (PCNA) is a sensitive marker that is detectable during the DNA synthesis or cell division (Cappello et al., 2006). This measurement information about cell proliferation (Suzuki, Kumamoto, Kunimori, \& Ooya, 2005) has provided information about the repair process of pulp tissue after a bleaching procedure.

Apoptosis is mitochondrial-mediated cell death (Cappello, Bellafiore, Palma, \& Bucchieri, 2002), and is key in homeostatic tissue mechanisms. Various stress factors can speed up the cleavage of pro-caspase- 3 in Caspase-3-cleaved (C3C) to apoptosis activation (Chandra, Choy, \& Tang, 2007), as $\mathrm{H}_{2} \mathrm{O}_{2}$. Once that inflammatory activity depends on equilibrium between proliferation and cell death, the investigation into the occurrence of these two mechanisms during pulp inflammation after dental bleaching with different $\mathrm{H}_{2} \mathrm{O}_{2}$ concentrations is important.

There are no in vivo studies about the effects of a bleaching procedure in pulp tissue regarding the levels of cell proliferation and apoptosis, yet such data would provide important information with which to understand mechanisms that involve pulp after this esthetics procedure. Thus, the purpose of this study was to provide an in vivo evaluation of the inflammatory response, levels of cell proliferation and apoptosis, and the presence of tissue necrosis after dental bleaching with two concentration of $\mathrm{H}_{2} \mathrm{O}_{2}$. Our hypothesis is that different $\mathrm{H}_{2} \mathrm{O}_{2}$ concentrations will not promote different responses in the pulp tissue.

\section{Materials and methods}

This research involved 40 albino male Wistar rats $(250 \mathrm{~g})$ that were housed in a temperature-controlled environment $\left(22^{\circ} \mathrm{C} \pm 1{ }^{\circ} \mathrm{C}\right)$ on a standard light/dark schedule with access to food and water ad libitum. The experimental protocol was approved by the institutional ethics committee at UNESP-Univ. Estadual Paulista (São Paulo, Brazil) and the study was conducted in accordance with relevant guidelines (CEUA 2014-00591).

\subsection{Tooth bleaching}

The rats were anesthetized by intramuscular injections of ketamine (80 mg/kg, Ketamina Agener 10\%, União Química Farmacêutica Nacional S/A - Embu-Guaçu, SP, Brasil) and xylazine $(10 \mathrm{mg} / \mathrm{kg}$, Xilazin, Syntec do Brazil LTDA - Cotia, SP, Brasil). The upper hemimaxillae were randomly divided into $(n=10)$ : The Control group received a placebo gel; the BLUE group was bleached with $20 \% \mathrm{H}_{2} \mathrm{O}_{2}$ (Whiteness HP Blue ${ }^{\circ}$ ); and the MAXX group was bleached with $35 \%$ $\mathrm{H}_{2} \mathrm{O}_{2}$ (Whiteness HP Maxx ${ }^{\circ}$ ). The application of the bleaching gel $(0.01 \mathrm{~mL})$ was performed in the molars (Cintra et al., 2013) according to the manufacturer's recommendations (FGM Dental Products, Joinville, SC, Brazil): 1 application for 50 min for BLUE group; 3 15-min applications for the MAXX group.

\subsection{Histology and immunohistochemical analysis}

At 2 and 30 days $(n=10)$, the animals were killed with an overdose of the Tiopental anesthetic (Thipentax, Cristália - Produtos Químicos Farmacêuticos Ltda - Itapira, Brasil). The hemi-maxillae were separated and fixed in a solution of $4 \%$ buffered formaldehyde for $24 \mathrm{~h}$. The specimens were decalcified in a $10 \%$ ethylenediaminetetraacetic acid (EDTA) solution for three months, and then dehydrated, clarified and embedded in paraffin.

The serial histological sections of each specimen were selected from the point where the mesial root of the first molar was seen in all its longitudinal extension. Five-micron sections were cut in the vestibularlingual plane. Two blades with four sections of each specimen were stained with hematoxylin-eosin (H.E.), or submitted to immunohistochemistry. The first blade obtained was selected for staining in H.E. and the next two for immunohistochemistry. This sequence was repeated, obtaining two blades for each staining. The immunohistochemistry was performed by using an indirect immunoperoxidase technique (Garcia et al., 2013) for PCNA (primary antibody mouse anti-PCNA, VP-P980, Vector Laboratories Inc., Burlingame, EUA) and C3C (primary antibody rabbit anti-C3C, Asp175, Cell Signaling Technology, Bervely, MA). The specimens were submitted to the previously described procedures that suppressed the use of primary antibodies for the negative control.

The analyses were performed by a single calibrated operator in a blinded manner under light microscopy $(400 \times$, DM 4000 B; Leica, Wetzlar, Germany). The pulp chamber was divided into thirds (occlusal, middle and cervical) as was the root pulp (cervical, middle and apical) (Cintra et al., 2013). The inflammation was scored in accordance with the approximate average number of inflammatory cells present in each third of the same specimen (Table 1) (Cintra, Benetti, Ferreira, Rahal et al., 2016).

The cell with brownish nucleus, in the case of PCNA, and brownish cytoplasm, in the case of $\mathrm{C} 3 \mathrm{C}$, were counted in each third of the pulp tissue and expressed in the number of cells per $\mathrm{mm}^{2}$. The area corresponding to the total volume and each third of the pulp chamber and root canal was performed with Leica Qwin Plus software (Leica", Germany).

\subsection{Statistical analysis}

Histological data were subjected to the Mann-Whitney statistical test, and the number of immunostained cells to a two-way ANOVA statistical test $(P<0.05)$.

\section{Results}

\subsection{Histological analysis}

Two days after dental bleaching, the specimens of the Control group showed pulp tissue in homeostasis, with continuous odontoblastic layers around the entire pulp and a negligible number of inflammatory cells (Fig. 1. a,d). Most specimens of the BLUE group $\left(20 \% \mathrm{H}_{2} \mathrm{O}_{2}\right)$ showed moderate inflammation in the occlusal third of the coronal pulp; mild or moderate inflammation in the middle third; and mild inflammation in the cervical third of the crown (Fig. 1. b,e). In most specimens of the MAXX group $\left(35 \% \mathrm{H}_{2} \mathrm{O}_{2}\right)$, there was necrosis in the region of the pulp horns; moderate inflammation in the middle third; and mild inflammation in the cervical third of the coronal pulp (Fig. 1. c,f).

\section{Table 1}

Scores attributed to the intensity of inflammatory cell infiltration.

\begin{tabular}{ll}
\hline Score & \multicolumn{1}{c}{ Pulpal tissue condition } \\
\hline 1 & Inflammatory cells absent or negligible in number \\
2 & Mild inflammatory infiltrate $(<25$ cells per field) \\
3 & Moderate inflammatory infiltrate (between 25 and 125 cells per field) \\
4 & Severe inflammatory infiltrate $(>125$ cells per field) \\
5 & Necrosis \\
\hline
\end{tabular}



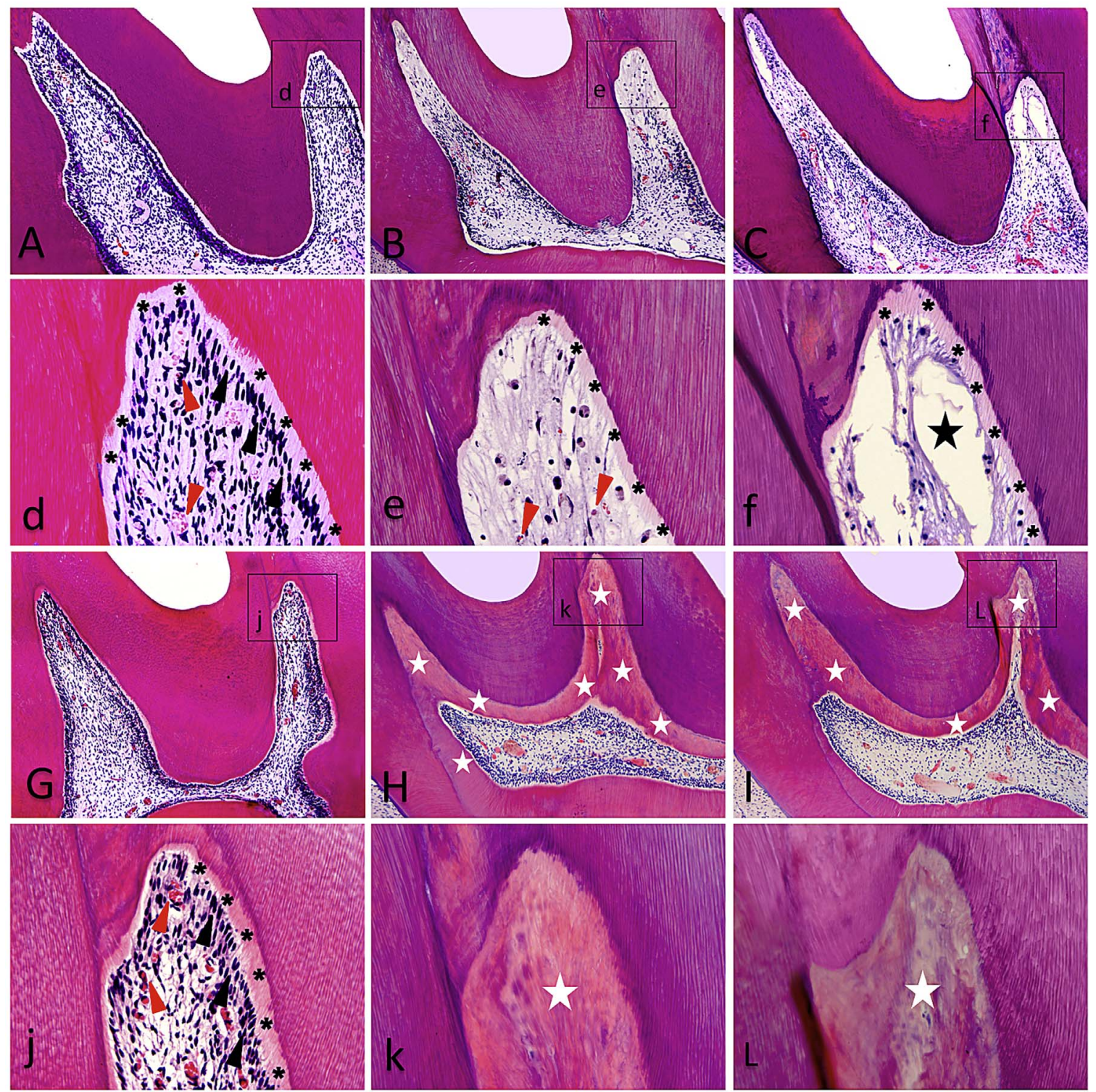

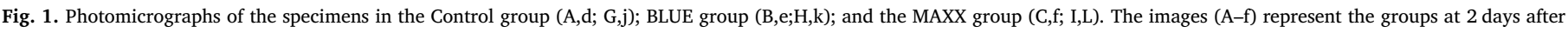

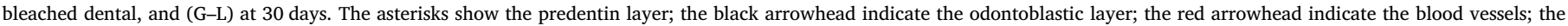
black star show the necrotic areas; and white star, tertiary dentin. Staining with hematoxylin-eosin. [A-C,G-I: $100 \times$; d-f,j-L: 400×].

Thirty days after dental bleaching, the specimens of all groups showed no inflammation. However, the bleached groups had tertiary dentin occupying area of the pulp chamber, especially in the crown (Fig. 1. H,k; I,L), which was not observed in the Control group (Fig. 1. G,j).

\subsection{Immunohistochemical analysis}

The positive immunolabeling for PCNA and C3C was found in diffusely distributed cells throughout the pulp. The level of proliferation was higher in the middle third of the coronal pulp in the BLUE group (Fig. 2. F), and in the cervical third in the MAXX group (Fig. 2. K). There was a lower level of proliferation in the root thirds (unexposed data) and at 30 days (Table 3). A higher level of apoptosis was found in the bleached groups at 2 days, particularly in the cervical third (Fig. 2. N,O), and at 30 days a similar level remained in the MAXX group and decreased in the BLUE group (Fig. 2. Q,R), as in root thirds (unexposed data). At 30 days, the number of immunolabeling cells was assessed only in the cervical third of the pulp chamber, because the occlusal and middle thirds of most specimens were occupied by tertiary dentin.

\subsection{Comparison among the groups}

At the two days after dental bleaching, the BLUE and MAXX groups showed a significant difference in the occlusal and middle thirds of the coronal pulp with more intense response in the MAXX group $(P<0.05$, Table 2$)$. In the cervical third there was no significant difference $(P>0.05$, Table 2$)$. There was no inflammation in the middle and apical thirds of the root (unexposed data).

The BLUE group showed higher immunolabeling for PCNA in the occlusal third at two days $(P>0.05)$; in the middle and cervical third, where there were significant differences among all groups: higher in the BLUE group in the middle third $(P<0.05)$, and higher in the MAXX group in the cervical third $(P<0.05)$. In the coronary and middle root thirds, there was a significant difference when comparing the groups bleached with control at two days. There was a significant decrease of immunolabeling cells in the cervical third at the 30 days for the bleached groups.

The immunolabeling for C3C showed a significant difference between the bleached and control groups, with higher immunolabeling 

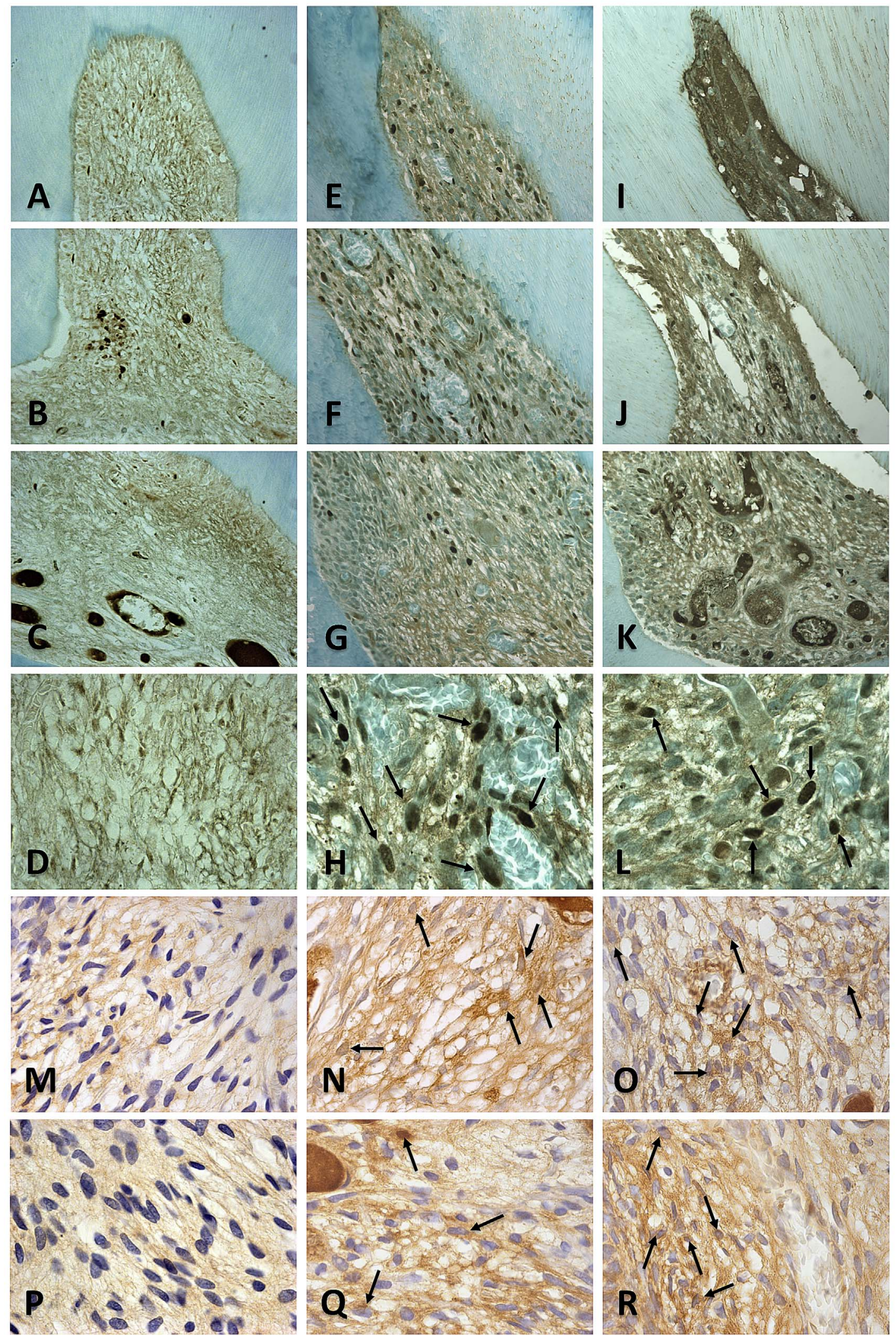

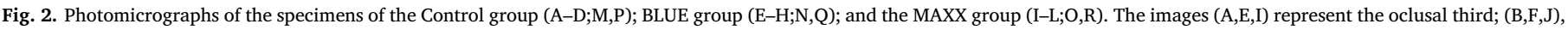

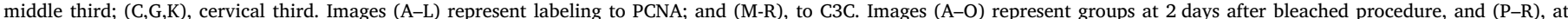
30 days. The arrows point to the immunolabeling cells. [A-C;E-G;I-K: $400 \times$; D,H,L;M-R: $1000 \times$ ]. 
Table 2

Scores Observed for Inflammatory Cell Response According to the groups.

\begin{tabular}{|c|c|c|c|c|c|c|}
\hline \multirow[t]{2}{*}{ Third } & & \multirow[t]{2}{*}{ Score 2 days } & \multicolumn{3}{|l|}{ Groups } & \multirow[t]{2}{*}{$\mathrm{P}$} \\
\hline & & & Control & BLUE & MAXX & \\
\hline \multirow[t]{18}{*}{ Coronal pulp } & Occlusal & 1 & $0 / 10$ & $0 / 10$ & $0 / 10$ & \\
\hline & & 2 & $0 / 10$ & $1 / 10$ & $0 / 10$ & Mann-Whitney \\
\hline & & 3 & $0 / 10$ & $5 / 10$ & $1 / 10$ & BLUE $\times$ MAXX $P=0,010$ \\
\hline & & 4 & $0 / 10$ & $3 / 10$ & $3 / 10$ & \\
\hline & & 5 & $0 / 10$ & $1 / 10$ & $6 / 10$ & \\
\hline & & Median* & 1 & $3^{\mathrm{a}}$ & $5^{\mathrm{b}}$ & \\
\hline & Middle & 1 & $10 / 10$ & $2 / 10$ & $0 / 10$ & \\
\hline & & 2 & $0 / 10$ & $5 / 10$ & $2 / 10$ & Mann-Whitney \\
\hline & & 3 & $0 / 10$ & $3 / 10$ & $5 / 10$ & BLUE $\times$ MAXX P $=0,013$ \\
\hline & & 4 & $0 / 10$ & $0 / 10$ & $2 / 10$ & \\
\hline & & 5 & $0 / 10$ & $0 / 10$ & $1 / 10$ & \\
\hline & & Median* & 1 & $2^{\mathrm{a}}$ & $3^{\mathrm{b}}$ & \\
\hline & Cervical & 1 & $10 / 10$ & $2 / 10$ & $2 / 10$ & \\
\hline & & 2 & $0 / 10$ & $8 / 10$ & $5 / 10$ & Mann-Whitney \\
\hline & & 3 & $0 / 10$ & $0 / 10$ & $3 / 10$ & BLUE $\times$ MAXX $P=0,304$ \\
\hline & & 4 & $0 / 10$ & $0 / 10$ & $0 / 10$ & \\
\hline & & 5 & $0 / 10$ & $0 / 10$ & $0 / 10$ & \\
\hline & & Median* & 1 & $2^{\mathrm{a}}$ & $2^{\mathrm{a}}$ & \\
\hline \multirow[t]{6}{*}{ Radicular pulp } & Cervical & 1 & $10 / 10$ & $8 / 10$ & $7 / 10$ & \\
\hline & & 2 & $0 / 10$ & $2 / 10$ & $3 / 10$ & Mann-Whitney \\
\hline & & 3 & $0 / 10$ & $0 / 10$ & $0 / 10$ & BLUE $\times$ MAXX P $=0,651$ \\
\hline & & 4 & $0 / 10$ & $0 / 10$ & $0 / 10$ & \\
\hline & & 5 & $0 / 10$ & $0 / 10$ & $0 / 10$ & \\
\hline & & Median* & 1 & $1^{\mathrm{a}}$ & $1^{\mathrm{a}}$ & \\
\hline
\end{tabular}

*Same letters on the line indicate no statistical difference among the groups $(P>0.05)$.

in the bleached groups, except in the occlusal third to two days for the MAXX and Control groups, due to a decrease of cellularity in the MAXX group. At 30 days, the immunolabeling of the cervical third of the BLUE group showed a significant decrease at 2 days $(P<0.05)$ that was not observed in the MAXX group $(P>0.05)$.

\section{Discussion}

This study evaluated the in vivo effects of the two concentrations of bleaching agents in the inflammatory response, the levels of cell proliferation and apoptosis, and the presence of tissue necrosis in the pulp tissue after the bleaching procedure. It was observed that the concentration of the bleaching agent influences the pulpal response, thus rejecting the null hypothesis.

The in vivo model has important characteristics that encourage study of the reactions of the pulp tissue against aggressors, due to cytoplasm extensions of odontoblast and dentin fluid that act as a physical barrier to the penetration of substances (Cintra, Benetti, Ferreira, Rahal et al., 2016), besides $\mathrm{H}_{2} \mathrm{O}_{2}$-degrading enzymes, minimizing damage to pulp (Esposito, Varvara, Murmura, Terlizzi, \& Caputi, 2003).

Studies in human teeth (Costa et al., 2010; Roderjan et al., 2014; Roderjan et al., 2015), animal teeth (Cintra et al., 2013; Cintra, Benetti, Ferreira, Gomes-Filho et al., 2016; Seale et al., 1981), and cell culture (Soares et al., 2011; Soares et al., 2013), show that the pulp of bleached teeth exhibits intense change in the form of severe inflammation or necrosis in first days after the bleaching procedure, as observed in this study. In a previous study, we have seen that the concentration of the bleaching gel can influence the capacity for $\mathrm{H}_{2} \mathrm{O}_{2}$ to penetrate the pulp chamber and, consequently, relate to damage within the dental pulp (Cintra, Benetti, Ferreira, Gomes-Filho et al., 2016). In the present study, we found that in the $35 \% \mathrm{H}_{2} \mathrm{O}_{2}$ group, $60 \%$ of the specimens showed necrosis in the occlusal third, while only $10 \%$ of the specimens that received bleaching gel with $20 \% \mathrm{H}_{2} \mathrm{O}_{2}$ showed necrosis, confirming the previous results.

However, these changes were shown to be reversible after a certain period, where the pulp is restructured and shows the formation of tertiary dentin. Other studies also show the reversal of such damage (Cintra, Benetti, Ferreira, Rahal et al., 2016; Seale et al., 1981; Soares, Basso, Hebling et al., 2015; Soares, Basso, Scheffel et al., 2015).

The positive immunolabeling for PCNA indicated proliferation in the pulp. Most immunolabeling was observed in regions where there probably was a lower penetration of ROS. These findings corroborate studies showing that low ROS concentrations stimulate growth and cell division (Davies, 1999; Min et al., 2008), which explains the proliferation observed in the pulp after the bleaching procedure.

The PCNA labeling was present after the topical application of carbamide peroxide or hydrogen in the oral mucosa of rats, where there was hyperplasia and hyperkeratosis (Weitzman, Weitberg, Stossel, Schwartz, \& Shklar, 1986). The proliferative effect of low doses of $\mathrm{H}_{2} \mathrm{O}_{2}$ was reported in odontoblasts, such as the induction of dentin

Table 3

Mean and Standard Deviation (SD) of count immunolabeling cells to PCNA and C3C in groups, expressed in number of cells per mm ${ }^{2}$.

\begin{tabular}{|c|c|c|c|c|c|c|c|}
\hline \multirow[t]{2}{*}{ Time } & \multirow[t]{2}{*}{ Third } & \multicolumn{3}{|c|}{ PCNA (Mean \pm SD)* } & \multicolumn{3}{|c|}{ Caspase-3-cleaved (Mean \pm SD)* } \\
\hline & & Control & BLUE & MAXX & Control & BLUE & MAXX \\
\hline 2 days & $\begin{array}{l}\text { Occlusal } \\
\text { Middle } \\
\text { Cervical }\end{array}$ & $\begin{array}{c}1,5 \pm 0,3^{\mathrm{a}} \\
2,1 \pm 0,7^{\mathrm{a}} \\
0 \pm 0^{\mathrm{aA}}\end{array}$ & $\begin{array}{c}121,5 \pm 40,2^{\mathrm{b}} \\
172,5 \pm 39,5^{\mathrm{b}} \\
113,0 \pm 32,7^{\mathrm{bA}}\end{array}$ & $\begin{array}{c}26,2 \pm 7,4^{\mathrm{a}} \\
65,0 \pm 17,3^{\mathrm{c}} \\
167,0 \pm 33,6^{\mathrm{cA}}\end{array}$ & $\begin{array}{c}3,8 \pm 1,2^{\mathrm{a}} \\
6,3 \pm 1,9^{\mathrm{a}} \\
9,0 \pm 3,0^{\mathrm{aA}}\end{array}$ & $\begin{array}{c}20,8 \pm 6,6^{\mathrm{b}} \\
20,4 \pm 5,9^{\mathrm{b}} \\
40,5 \pm 12,3^{\mathrm{bA}}\end{array}$ & $\begin{array}{c}6,9 \pm 2,1^{\mathrm{a}} \\
27,5 \pm 7,7^{\mathrm{b}} \\
37,5 \pm 10,9^{\mathrm{bA}}\end{array}$ \\
\hline 30 days & Cervical & $3 \pm 1,0^{\mathrm{aA}}$ & $20,7 \pm 6,8^{\mathrm{aB}}$ & $7,1 \pm 2,2^{\mathrm{aB}}$ & $6,5 \pm 2,1^{\mathrm{aA}}$ & $24,4 \pm 7,6^{\mathrm{bB}}$ & $45,9 \pm 15,1^{\mathrm{cA}}$ \\
\hline
\end{tabular}

*Different small letters represent statistical difference in lines; different uppercase letters represent statistical difference between 2 and 30 days of the cervical third $(P>0.05)$. 
formation (Min et al., 2008). The expression of osteogenic markers in human dental pulp cells also increased (Matsui et al., 2009). ROS generated by the low power laser promoted wound healing (Mester, Mester, \& Mester, 1985), the differentiation of pre-odontoblastics cells, increased the amount of tertiary dentin after 12 weeks of treatment and increased $\mathrm{H}_{2} \mathrm{O}_{2}$ in cells (Arany et al., 2014).

Already at higher concentrations, the cells simply disintegrate or become necrotic due to the disruption of the cell membrane (Davies, 1999). The same outcome is seen in the occlusal third of the pulp in the MAXX group. At 30 days, immunolabeling for PCNA was not observed, indicating an absence of cell proliferation.

At the two days after dental bleaching, we observed an increase of immunolabeling cells to $\mathrm{C} 3 \mathrm{C}$ in bleached specimens, except in the occlusal third of the MAXX group, due to necrosis. Studies show that moderate concentrations of $\mathrm{H}_{2} \mathrm{O}_{2}$ lead the cells to apoptosis and, at high concentrations, to necrosis (Davies, 1999; Saito et al., 2006). In this study, the apoptotic cells were found in greater amounts in the most distant regions of the bleaching gel, with a likely lower penetration of $\mathrm{H}_{2} \mathrm{O}_{2}$; in the most superficial areas of pulp tissue, there was the process of necrosis. This finding can be confirmed by comparing the effects of two concentrations of bleaching agents on the pulp, where the occlusal third showed necrosis in the MAXX group, possibly due to the highest concentration of $\mathrm{H}_{2} \mathrm{O}_{2}$, and higher amounts of immunolabeling cells to $\mathrm{C} 3 \mathrm{C}$ in the BLUE group. Both mechanisms of cell death occur independent of each other, and dependent on contact time with $\mathrm{H}_{2} \mathrm{O}_{2}$, apoptosis can occur in the presence of necrotic cells (Saito et al., 2006), as in this study.

Apoptosis is necessary in order for odontoblasts to maintain a dentin deposition rate (Mitsiadis, De Bari, \& About, 2008), given that during odontogenesis or deposition of the secondary or tertiary dentin, apoptosis eliminates the odontoblasts that have achieved their genetic program (Kim et al., 2006; Mitsiadis et al., 2008), or that are affected during a tooth injury (Mjor, 1985), regulating the tooth maturation, the pulp chamber remodeling, and homeostasis (Mitsiadis et al., 2008). Apoptosis also leads to the formation of mature dental pulp when exposed to extraneous stimuli (Mitsiadis \& Rahiotis, 2004). This may indicate that the presence of immunolabeling for C3C is related to the aging of the pulp. The MAXX group showed no significant difference when comparing the cervical thirds of the coronal pulp at 2 and 30 days, indicating that the highest concentration of $\mathrm{H}_{2} \mathrm{O}_{2}$ was able to maintain the apoptotic effect for a long period of time. It may be that the pulp tissue is further completed by tertiary dentine, due to the extended effect of the bleaching gel.

However, we must consider that there are not only differences in $\mathrm{H}_{2} \mathrm{O}_{2}$ concentration when the MAXX and BLUE groups are compared: there is also the difference regarding the application protocols, the composition and pH of bleaching gels (Basting, Amaral, França, \& Flório, 2012; Kossatz, Martins, Loguercio, \& Reis, 2012; Marson et al., 2015; Mena-Serrano et al., 2015; Torres, Crastechini, Feitosa, Pucci, \& Borges, 2014). It has been shown that the penetration of $\mathrm{H}_{2} \mathrm{O}_{2}$ in the tooth structure is timedependent and is enhanced by increasing the permanence time of the product on the tooth surface (Marson et al., 2015). Moreover, the use of home-use $20 \%$ peroxide carbamide has produced more sensitivity in patients when compared to the use of in-office bleaching gel, which may be ascribed to the amount of time that the gels are in contact with the dental structure (Basting et al., 2012). In spite of these results, our previous study showed that three applications of the gel of greater concentration allow greater diffusion of $\mathrm{H}_{2} \mathrm{O}_{2}$ to the pulp chamber (Cintra, Benetti, Ferreira, Gomes-Filho et al., 2016), increasing damage to the dental pulp, which corroborates with the results of the present study. Mena-Serrano et al. (2015) also observed a greater penetration of $\mathrm{H}_{2} \mathrm{O}_{2}$ when the bleaching gel was renewed on the tooth surface.

The composition of the bleaching gels used in the study are also different, mainly due to the presence of calcium in the BLUE gel, which is able to significantly reduce the penetration of $\mathrm{H}_{2} \mathrm{O}_{2}$ in the pulp chamber (Mena-Serrano et al., 2015) by decreasing the permeability of tooth surface (Matis, Cochran, Eckert, \& Matis, 2007). Calcium also helps to maintain the stable and high pH of the BLUE gel (Kossatz et al., 2012), which causes more $\mathrm{H}_{2} \mathrm{O}_{2}$ to dissociate into free radicals, reducing the surplus $\mathrm{H}_{2} \mathrm{O}_{2}$ that penetrates the pulp chamber (MenaSerrano et al., 2015). However, there are still controversies regarding the $\mathrm{pH}$ effects of the bleaching gel: Studies indicate that the efficacy of the bleaching gel is directly proportional to the increase of its $\mathrm{pH}$ (Torres et al., 2014), and that neutral pH is important to minimize potential damage (Price, Sedarous, \& Hiltz, 2000). Generally speaking, bleaching gels from different manufacturers have variable $\mathrm{pH}$ levels, and further studies are needed to clarify the $\mathrm{pH}$ influence of bleaching gels on the effects caused by dental bleaching.

The results of the present study cannot be directly extrapolated to the effects in human teeth, but they contribute significantly to our understanding of the effects of bleaching gel in the dental pulp. We note that even when used in a low concentration, the $\mathrm{H}_{2} \mathrm{O}_{2}$ can stimulate the tissue in response to the presence of the aggressive agent, thus accelerating the aging pulp. Still, the most damaged cells may enter into apoptosis. This outcome is alarming because the odontoblasts constitute the first layer of pulp cells and are the first to be damaged (Cooper et al., 2010).

Still, this study shows that the pulp tissue is able to recover, even after severe damage caused by $\mathrm{H}_{2} \mathrm{O}_{2}$. This finding could explain the fact that patients report intense tooth sensitivity during the first days after dental bleaching, which disappears over time (Martin et al., 2013). Severe damage was reported in the literature by the bleaching gel in human mandibular incisors (Costa et al., 2010; Roderjan et al., 2014; Roderjan et al., 2015), but histological studies that show long-term results are lacking. These studies would be important to confirm the results of our study. Thus, bleaching gels with a higher concentration of $\mathrm{H}_{2} \mathrm{O}_{2}$ should be used with caution since they can cause greater damage, such as necrosis, and maintain a prolonged level of apoptosis. Other in vivo studies are needed to elucidate the understanding of the mechanisms that occur within pulp after a dental bleaching procedure.

\section{Conclusion}

In conclusion, the concentration of $\mathrm{H}_{2} \mathrm{O}_{2}$ influences the damage to pulp tissue, whereas lower concentrations cause inflammation, cell proliferation and apoptosis in tissue and higher concentrations lead to tissue necrosis. This damage is later repaired, but the use of high concentrations of $\mathrm{H}_{2} \mathrm{O}_{2}$ can maintain a prolonged apoptotic effect. These effects can indicate a likely anticipated aging of the pulp tissue, which can decrease its capacity to respond to new aggressors.

\section{Competing interests}

The authors have no conflict of interest.

\section{Funding}

The work was supported by São Paulo State Research Foundation-FAPESP (num. 2013/25429-0).

\section{References}

Arany, P. R., Cho, A., Hunt, T. D., Sidhu, G., Shin, K., Hahm, E., et al. (2014) Photoactivation of endogenous latent transforming growth factor-b1 directs dental stem cell differentiation or regeneration. Science Translational Medicine, 6(238), 238 ra69.

Azer, S. S., Machado, C., Sanchez, E., \& Rashid, R. (2009). Effect of home bleaching systems on enamel nanohardness and elastic modulus. Journal of Dentistry, 37(3), 185-190.

Basting, R. T., Amaral, F. L., França, F. M., \& Flório, F. M. (2012). Clinical comparative study of the effectiveness of and tooth sensitivity to $10 \%$ and $20 \%$ carbamide peroxide home-use and 35\% and 38\% hydrogen peroxide in-office bleaching materials containing desensitizing agents. Operative Dentistry, 37(5), 464-473.

Bistey, T., Nagy, I. P., Simo, A., \& Hegedus, C. (2007). In vitro FT-IR study of the effects of hydrogen peroxide on superficial tooth enamel. Journal of Dentistry, 35(4), 325-330. Bonafé, E., Bacovis, C. L., Iensen, S., Loguercio, A. D., Reis, A., \& Kossatz, S. (2013). Tooth 
sensitivity and efficacy of in-office bleaching in restored teeth. Journal of Dentistry 41(4), 363-369.

Cappello, F., Bellafiore, M., Palma, A., \& Bucchieri, F. (2002). Defective apoptosis and tumorigenesis: Role of p53 mutation and Fas/FasL system dysregulation. European Journal of Histochemistry, 46(3), 199-208.

Cappello, F., Di Stefano, A., David, S., Rappa, F., Anzalone, R., La Rocca, G., et al. (2006). Hsp60 and Hsp10 down-regulation predicts bronchial epithelial carcinogenesis in smokers with chronic obstructive pulmonary disease. Cancer, 107(10), 2417-2424.

Chandra, D., Choy, G., \& Tang, D. G. (2007). Cytosolic accumulation of HSP60 during apoptosis with or without apparent mitochondrial release: Evidence that its proapoptotic or pro-survival functions involve differential interactions with caspase-3. The Journal of Biological Chemistry, 282(43), 31289-31301.

Cintra, L. T., Benetti, F., Facundo, A. C. S., Ferreira, L. L., Gomes-Filho, J. E., Ervolino, E., et al. (2013). The number of bleaching sessions influences pulp tissue damage in rat teeth. Journal of Endodontics, 39(12), 1576-1580.

Cintra, L. T., Benetti, F., Ferreira, L. L., Gomes-Filho, J. E., Ervolino, E., Gallinari, M. O., et al. (2016). Penetration capacity color alteration and biological response of two inoffice bleaching protocols. Brazilian Dental Journal, 27(2), 169-175.

Cintra, L. T., Benetti, F., Ferreira, L. L., Rahal, V., Ervolino, E., Jacinto, R. C., et al. (2016). Evaluation of an experimental rat model for comparative studies of bleaching agents. Journal of Applied Oral Science, 24(2), 171-180.

Cintra, L. T., Ferreira, L. L., Benetti, F., Gomes-Filho, J. E., Ervolino, E., \& Briso, A. L. F. (2016). Diabetes influence pulpal tissue response after dental bleaching. International Endodontic Journal. http://dx.doi.org/10.1111/iej.12692.

Cooper, P. R., Takahashi, Y., Graham, L. W., Simon, S., Imazato, S., \& Smith, A. J. (2010). Inflammation-regeneration interplay in the dentine-pulp complex. Journal of Dentistry, 38(9), 687-697.

Costa, C. A., Riehl, H., Kina, J. F., Sacono, N. T., \& Hebling, J. (2010). Human pulp responses to in-office tooth bleaching. Oral Surgery, Oral Medicine, Oral Pathology, Oral Radiology, and Endodontology, 109(4), e59-64.

Davies, K. J. (1999). The broad spectrum of responses to oxidants in proliferating cells: A new paradigm for oxidative stress. IUBMB Life, 48(1), 41-47.

Esposito, P., Varvara, G., Murmura, G., Terlizzi, A., \& Caputi, S. (2003). Ability of healthy and inflamed human dental pulp to reduce hydrogen peroxide. European Journal of Oral Sciences, 111(5), 454-456.

Ferreira, V. G., Nabeshima, C. K., Marques, M. M., Paris, A. F., Gioso, M. A., dos Reis, R. S., et al. (2013). Tooth bleaching induces changes in the vascular permeability of rat incisor pulps. American Journal of Dentistry, 26(5), 298-300.

Ferreira, L.L., Gomes-Filho, J.E., Benetti, F., Carminatti, M., Ervolino, E., Briso, A.L.F., Cintra, L.T., The effect of dental bleaching on pulpal tissue response in a diabetic animal model: Immunoregulatory cytokines study, International Endodontic Journal, (accepted article for publication).

Garcia, V. G., Longo, M., Gualberto-Júnior, E. C., Bosco, A. F., Nagata, M. J., Ervolino, E., et al. (2013). Effect of the concentration of phenothiazine photosensitizers in antimicrobial photodynamic therapy on bone loss and the immune inflammatory response of induced periodontitis in rats. Journal of Periodontal Research, 49(5), 584-594.

Kim, J. Y., Cha, Y. G., Cho, S. W., Kim, E. J., Lee, M. J., Lee, J. M., et al. (2006). Inhibition of apoptosis in early tooth development alters tooth shape and size. Journal of Dental Research, 85(6), 530-535.

Kossatz, S., Martins, G., Loguercio, A. D., \& Reis, A. (2012). Tooth sensitivity and bleaching effectiveness associated with use of a calcium-containing in-office bleaching gel. Journal of American Dental Association, 143(12), e81-87.

Lee, D. H., Lim, B. S., Lee, Y. K., \& Yang, H. C. (2006). Effects of hydrogen peroxide (H2O2) on alkaline phosphatase activity and matrix mineralization of odontoblast and osteoblast cell lines. Cell Biology and Toxicology, 22(1), 39-46.

Marson, F. C., Gonçalves, R. S., Silva, C. O., Cintra, L. T., Pascotto, R. C., Santos, P. H., et al. (2015). Penetration of hydrogen peroxide and degradation rate of different bleaching products. Operative Dentistry, 40(1), 72-79.

Martin, J., Fernandez, E., Bahamondes, V., Werner, A., Elphick, K., Oliveira-Jr, O. B., et al. (2013). Dentin hypersensitivity after teeth bleaching with in-office systems Randomized clinical trial. American Journal of Dentistry, 26(1), 10-14.

Matis, B. A., Cochran, M. A., Eckert, G. J., \& Matis, J. I. (2007). In vivo study of two carbamide peroxide gels with different desensitizing agents. Operative Dentistry, 32(6), 549-555.

Matsui, S., Tsujimoto, Y., \& Matsushima, K. (2007). Stimulatory effects of hydroxyl radical generation by Ga-Al-As laser irradiation on mineralization ability of human dental pulp cells. Biological and Pharmaceutical Bulletin, 30(1), 27-31.

Matsui, S., Takahashi, C., Tsujimoto, Y., \& Matsushima, K. (2009). Stimulatory effects of low-concentration reactive oxygen species on calcification ability of human dental pulp cells. Journal of Endodontics, 35(1), 67-72.

Mena-Serrano, A. P., Parreiras, S. O., do Nascimento, E. M., Borges, C. P., Berger, S. B., Loguercio, A. D., et al. (2015). Effects of the concentration and composition of inoffice bleaching gels on hydrogen peroxide penetration into the pulp chamber. Operative Dentistry, 40(2), E76-82.

Mester, E., Mester, A. F., \& Mester, A. (1985). The biomedical effects of laser application. Lasers in Surgery and Medicine, 5(1), 31-39.

Min, K. S., Lee, H. J., Kim, S. H., Lee, S. K., Kim, H. R., Pae, H. O., et al. (2008). Hydrogen peroxide induces heme oxygenase- 1 and dentin sialophosphoprotein mRNA in human pulp cells. Journal of Endodontics, 34(8), 983-989.

Mitsiadis, T. A., \& Rahiotis, C. (2004). Parallels between tooth development and repair: Conserved molecular mechanisms following carious and dental injury. Journal of Dental Research, 83(12), 896-902.

Mitsiadis, T. A., De Bari, C., \& About, I. (2008). Apoptosis in developmental and repairrelated human tooth remodeling: A view from the inside. Experimental Cell Research, 314(4), 869-877.

Mjor, I. A. (1985). Dentin-predentin complex and its permeability: Pathology and treatment overview. Journal of Dental Research, 64, 621-627.

Pintado-Palomino, K., Peitl Filho, O., Zanotto, E. D., \& Tirapelli, C. (2015). A clinical randomized, controlled study on the use of desensitizing agents during tooth bleaching. Journal of Dentistry, 43(9), 1099-1105.

Price, R. B., Sedarous, M., \& Hiltz, G. S. (2000). The pH of tooth-whitening products. Journal (Canadian Dental Association), 66(8), 421-426.

Roderjan, D. A., Stanislawczuk, R., Hebling, J., Costa, C. A., Soares, D. G., Reis, A., et al. (2014). Histopathological features of dental pulp tissue from bleached mandibular incisors. Journal of Materials Science and Engineering B, 4(6), 178-185.

Roderjan, D. A., Stanislawczuk, R., Hebling, J., Costa, C. A., Reis, A., \& Loguercio, A. D. (2015). Response of human pulps to different in-office bleaching techniques: Preliminary findings. Brazilian Dental Journal, 26(3), 242-248.

Saito, Y., Nishio, K., Ogawa, Y., Kimata, J., Kinumi, T., Yoshida, Y., et al. (2006). Turning point in apoptosis/necrosis induced by hydrogen peroxide. Free Radical Research, 40(6), 619-630.

Sanz, A., Gómez, J., Caro, P., \& Barja, G. (2006). Carbohydrate restriction does not change mitochondrial free radical generation and oxidative DNA damage. Journal of Bioenergetics and Biomembranes, 38, 327-333.

Seale, N. S., McIntosh, J. E., \& Taylor, A. N. (1981). Pulpal reaction to bleaching of teeth in dogs. Journal of Dental Research, 60(5), 948-953.

Soares, D. G., Ribeiro, A. P., Sacono, N. T., Coldebella, C. R., Hebling, J., \& Costa, C. A. (2011). Transenamel and transdentinal cytotoxicity of carbamide peroxide bleaching gels on odontoblast-like MDPC-23 cells. International Endodontic Journal, 44(2), $116-125$.

Soares, D. G., Pontes, E. C., Ribeiro, A. P., Basso, F. G., Hebling, J., \& Costa, C. A. (2013). Low toxic effects of a whitening strip to cultured pulp cells. American Journal of Dentistry, 26(5), 283-285.

Soares, D. G., Basso, F. G., Hebling, J., \& de Souza Costa, C. A. (2015). Immediate and late analysis of dental pulp stem cells viability after indirect exposition to alternative inoffice bleaching strategies. Clinical Oral Investigations, 19(5), 1013-1020.

Soares, D. G., Basso, F. G., Scheffel, D. S., Hebling, J., \& de Souza Costa, C. A. (2015) Responses of human dental pulp cells after application of a low-concentration bleaching gel to enamel. Archives of Oral Biology, 60(9), 1428-1436.

Suzuki, T., Kumamoto, H., Kunimori, K., \& Ooya, K. (2005). Immunohistochemical analysis of apoptosis-related factors in lining epithelium of radicular cysts. Journal of Oral Pathology \& Medicine, 34(1), 46-52.

Torres, C. R., Crastechini, E., Feitosa, F. A., Pucci, C. R., \& Borges, A. B. (2014). Influence of $\mathrm{pH}$ on the effectiveness of hydrogen peroxide whitening. Operative Dentistry, 39(6), E261-268.

Weitzman, A. S., Weitberg, A. B., Stossel, T. P., Schwartz, J., \& Shklar, G. (1986). Effects of hydrogen peroxide on oral carcinogenesis in Hamsters. Journal of Periodontology, 57(11), 685-688.

Wu, T. T., Li, L. F., Du, R., Jiang, L., \& Zhu, Y. Q. (2013). Hydrogen peroxide induces apoptosis in human dental pulp cells via caspase-9 dependent pathway. Journal of Endodontics, 39(9), 1151-1155. 